Article

\title{
Urban Scale Application of Solar PV to Improve Sustainability in the Building and the Energy Sectors of KSA
}

\author{
Muhammad Asif
}

Architectural Engineering Department, King Fahd University of Petroleum and Minerals, Dhahran 31261, Saudi Arabia; asifm@kfupm.edu.sa

Academic Editor: Francesco Nocera

Received: 31 July 2016; Accepted: 24 October 2016; Published: 3 November 2016

\begin{abstract}
The Kingdom of Saudi Arabia (KSA) is the largest country in the Gulf Cooperation Council (GCC) region in terms of population, geographic area, economy, and construction and utility infrastructure. The rapid growth of the building sector in general and residential buildings in particular is creating huge energy and environmental challenges for the country. To address these problems and reduce its reliance on an oil-based energy infrastructure, the country aims to install $9.5 \mathrm{GW}$ of renewable energy by 2030. Traditionally the emphasis has been on large-scale renewable projects. Globally, the recent success of solar energy has been significantly contributed by the application of photovoltaics (PV) in buildings. This is an area that has been overlooked in KSA. This study investigates the prospects of application of PV in buildings to improve the sustainability standards in the building and energy sectors of the country by considering the King Fahd University of Petroleum and Minerals (KFUPM) as a case study. PVsyst and RetScreen software programs have been used to model the application of PV on building rooftops in KFUPM. The study also discusses the concerned policy. It is found that the rooftop application of PV can annually produce $37,746 \mathrm{MWh}$ of electricity, meeting over $16 \%$ of the KFUPM's total energy requirements.
\end{abstract}

Keywords: solar energy; buildings; sustainability; PV; rooftop; residential sector; Saudi Arabia

\section{Introduction}

The role of renewable energy in meeting global energy needs is becoming ever more important. Due to its advantages, like a widely and abundantly available resource base, environmental friendliness and declining price trends, over the last couple of decades, renewable energy has experienced a rapid growth across the world. Statistics suggest that renewable technologies have now surpassed fossil fuel-based technologies in terms of annual capacity addition at the global level. Renewable technologies, contributing to over $23 \%$ of the global power generation, attracted a record 286 billion US\$ of new investment in the year 2015. Solar photovoltaics (PV) are one of the most prominent renewable technologies. In 2015 it experienced an annual growth rate of over $28 \%$ with the net global installed capacity reaching at $227 \mathrm{GW}[1,2]$. Over 22 countries in the world are meeting more than $1 \%$ of their power requirements from PV. Italy, Greece and Germany are the leading countries in the world in terms of percentage of their power generation coming from PV with respective shares of $7.8 \%$, $6.5 \%$ and $6.4 \%$.

Small-scale and building-integrated applications have provided a substantial proportion of the global PV capacity. Germany, for example, the world's leading country in solar PV installed capacity, benefits mainly from small-scale systems. Having pioneered the feed-in tariff (FIT) concept in the early 1990s, it has managed to establish a large base of small-scale PV power producers, mainly from the residential sector. Germany's successful FIT policy has been replicated elsewhere in the world 
and countries like Italy, Japan, Spain, UK and USA have also seen their PV market rapidly flourish. Since 2010, UK, for example, has seen its PV capacity grow exponentially due to conducive policies like FIT and renewable obligation certificates (ROC). Statistics reveal that the installed capacity of PV in UK has jumped from less than $50 \mathrm{MW}$ at the start of 2010 to over 10,000 MW by the beginning of 2016 [3]. Over the five-year period between 2010 and 2015, the FIT has supported development of over $3700 \mathrm{MW}$ of renewables of which around $87 \%$ has been through solar PV. Over $70 \%$ of the PV projects supported under the FIT scheme are small scale (under $10 \mathrm{~kW}$ ) [4]. FIT is now being practiced in over 50 countries across the world [5]. In developing countries, other types of business models such as micro-credit-based systems have enabled PV to gain significant ground in the national power supply base.

Saudi Arabia is the largest country in the Arabian Peninsula in terms of population, geographic outreach and economy. It is also one of the richest countries in the world in terms of oil and gas reserves, leading to an energy-affluent lifestyle. Over the last few decades, in the pursuit of development and modernization, the country has experienced a rapid growth in the building and construction sector $[6,7]$. Owing to factors like rising population, modernization and economic development, between 2009 and 2025 , the electricity demand in the residential sector is expected to more than double. While around two-third of the population is under the age of 30 years, estimates suggest that in order to meet the needs of the growing population, the country has to build 2.32 million new homes by 2020 [8-10]. Already one of the highest countries in the world in terms of per capita energy consumption and carbon dioxide emissions, the situation there is going to significantly add to the energy and environmental burdens it faces [6]. For sustainable development, the situation requires a major shift in the energy consumption patterns in the building sector. Besides energy conservation strategies, use of renewable technologies can significantly help improve the energy and environmental footprint of buildings. Traditionally Saudi Arabia has relied on fossil fuels to meet its energy requirements. Despite having taken initiatives more than three decades ago, the country is yet to see renewable energy making any considerable inroads in its energy and building sectors. Key barriers in this respect include huge public subsidies for fossil fuels, government preferences to large scale and centralized projects, investment risks, lack of administrative experience with renewable technologies, and regulatory issues.

Saudi Arabia is now keen to diversify its energy base by exploiting its renewable resources. Strong solar radiation levels amounting to an average yearly value of over $2200 \mathrm{kWh} / \mathrm{m}^{2}$ are one of the key strengths of the country's renewable base [6]. The country has given itself a target of setting up $9.5 \mathrm{GW}$ renewables by 2030, most of which is projected to come from solar energy [11]. The focus of the country thus far has been on large or industrial scale projects overlooking the application of PV in buildings. This is an area that needs attention. Besides developing large scale PV projects, KSA also needs to exploit its small-scale generation potential especially through the building sector.

This study aims to examine the prospects of urban scale application of PV systems in the King Fahd University of Petroleum and Minerals (KFUPM). Given its large and diverse building infrastructure, population and energy demand, KFUPM is regarded to be a suitable case study area at urban scale level. The whole building infrastructure of the university campus has been examined for utilizable roof top area for PV application. Energy yield from the designed rooftop PV systems has been modeled with the help of PVsyst software. The study also provides emission analysis with the help of RetScreen software besides discussing policy guidelines to promote PV systems in the Saudi building sector.

\section{The Energy Outlook of KSA and Solar Energy Initiatives}

Saudi Arabia is among the leading countries in the world in terms of per capita energy consumption. The building sector is one of the main contributors of energy and environmental challenges facing the country. It has a fast-growing building sector with over $43 \%$ of all new construction projects within the GCC region, as shown in Figure 1 [6]. This situation translates into rapid growth in demand for energy from this sector adding to the stresses on the national energy and environmental scenarios. Buildings account for nearly $80 \%$ of the national electricity consumption, 
a figure well above the global average. Residential buildings alone consume over $51 \%$ of the total electricity [12-16]. Heavily subsidized energy prices have been an important factor in energy-expensive life style. A comparison of electricity tariffs in KSA with a number of other countries is provided in Figure 2 [17]. The electricity prices in KSA are on the higher end when compared with other GCC countries as well. Over the last couple of decades KSA has experienced a steep rise in energy demand as shown in Figure 3 [18]. The annual growth rates in electricity consumption and the number of consumers over the last decade have been reported to be as much as $8 \%$ and $5 \%$ respectively [19]. Forecasts suggest that by 2040, the electricity consumption in KSA will increase from the current figure of $277 \mathrm{TWh} /$ Year to as much as $850 \mathrm{TWh} /$ Year. The situation is projected to require the installed power generation capacity to reach up to $185,000 \mathrm{MW}$, requiring an annual addition of $4200 \mathrm{MW}$. In the oil and gas perspective which are the main sources for power generation in Saudi Arabia, the final consumption is forecasted to increase from 105 Mtoe (Million Ton of Oil Equivalent) in 2009 to about 425 Mtoe with total production of Saudi Arabia estimated at 534 Mtoe [20]. Such a massive surge in demand is bound to have enormous impact not only on the energy and environmental but also the economic outlook of the country as export of oil and gas has traditionally been the backbone of its national revenues. The situation demands a paradigm shift in energy generation and consumption patterns.

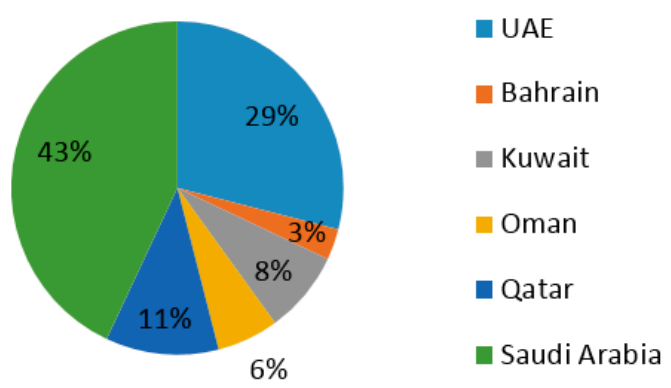

Figure 1. Building infrastructure projects under development in GCC.

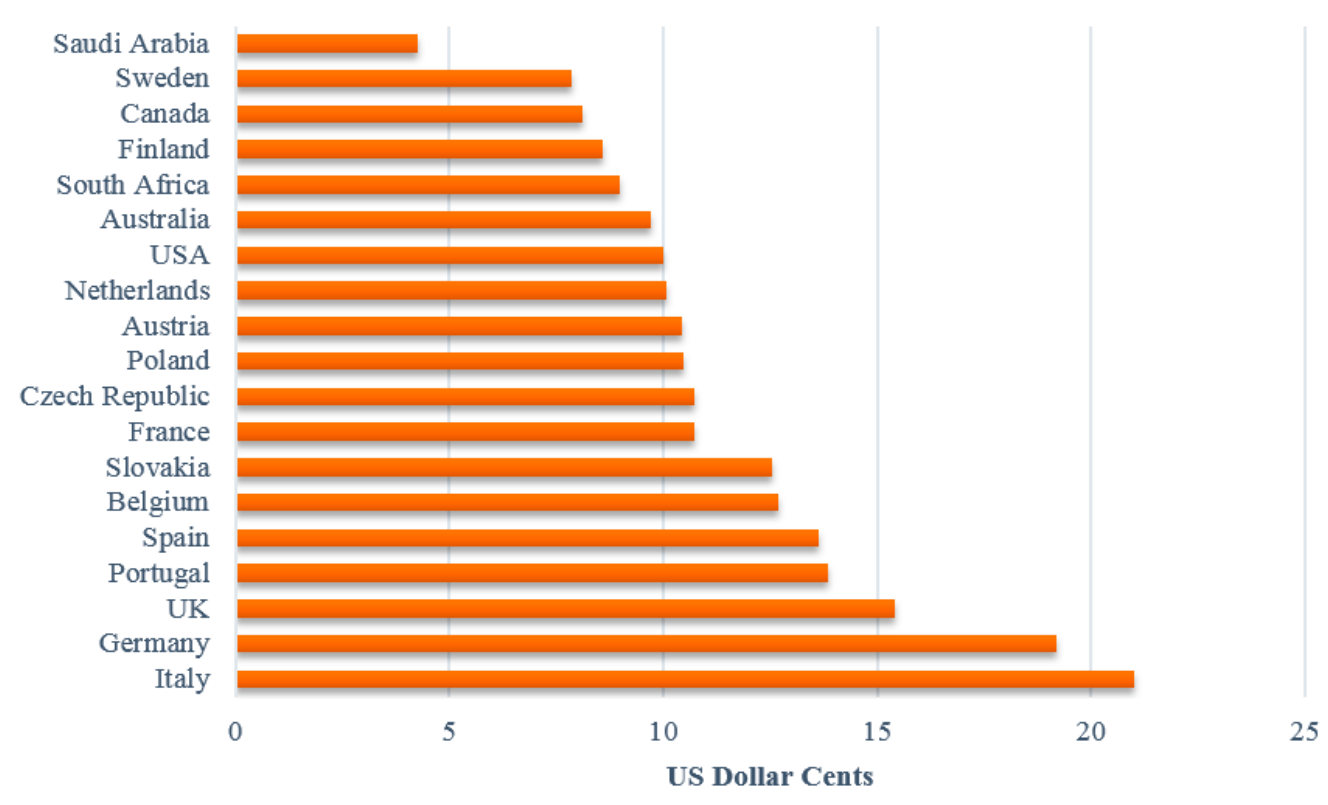

Figure 2. Comparison of electricity tariff in KSA with developed countries. 


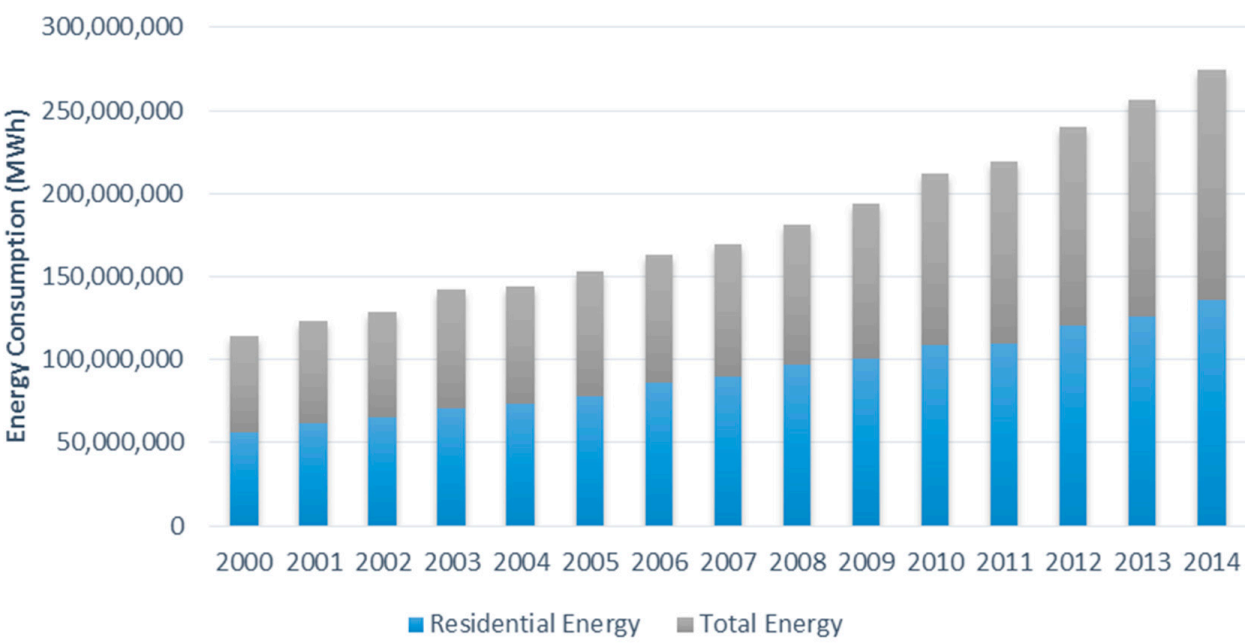

Figure 3. Growth trend of energy demand in KSA.

Renewable energy is widely deemed to be an appropriate solution to address energy and environmental challenges across the world. It offers inexhaustible, widely distributed and environmentally friendly energy generation opportunities through solar energy, wind power, bioenergy, hydropower, wave and tidal power and geothermal energy. Solar PV is one of the fastest growing renewable energy technologies. Application of solar PV has been a great success in many countries including Germany, Italy, Spain, Japan and USA. Interestingly, the main contribution in all these countries comes from the application of PV in buildings.

Saudi Arabia has targeted the development of $9.5 \mathrm{GW}$ of renewable energy by 2030 in its latest national roadmap, Vision 2030 [21]. The vast majority of this target has to be met through solar technologies like PV and solar thermal power. However given the huge growth requirements in annual installed capacity, traditionally the focus has been on large scale power generation projects. The same applies to plans for solar power, so there has not been any emphasis on small-scale or building-integrated PV systems as yet. Saudi Arabia developed its first solar PV project, Saudi Solar Village, with $350 \mathrm{~kW}$ capacity, in 1981 to supply power to almost 3000 inhabitants in a remote village. The project encountered several technical issues predominantly due to harsh weather conditions [22]. It was followed up with another experimental project of the same capacity to produce hydrogen in 1993. These two experimental projects did not see any considerable follow up initiatives until a $2 \mathrm{MW}$ solar PV project was developed in 2010 in the King Abdullah University of Science and Technology as indicated in Table 1. In recent years there have been a few other large-scale projects such as the $10 \mathrm{MW}$ solar car parking project developed by Saudi ARAMCO in 2011. Over this whole period, there have not been any notable projects of application of PV in buildings. Other significant developments at the regional level include the 10 MW Masdar City Solar PV Plant developed in 2009. While the Zero Carbon City project of the Masdar City, involving development of sustainable homes also utilizing PV systems, is scheduled to be completed in 2016, it is facing delays [23,24].

Table 1. Track record of PV projects in KSA [22,25].

\begin{tabular}{lcc}
\hline \multicolumn{1}{c}{ Project } & Capacity & Commencement Date \\
\hline King Abdulaziz International Airport Development Project & $5.4 \mathrm{MW}$ & 2013 \\
KAPSARC Project & $3.5 \mathrm{MW}$ & 2013 \\
Saudi ARAMCO Solar car Park & $10.5 \mathrm{MW}$ & 2012 \\
King Abdullah Financial District Project & $200 \mathrm{~kW}$ & 2012 \\
KAUST Solar Park & $2 \mathrm{MW}$ & 2010 \\
PV Hydrogen Project & $350 \mathrm{~kW}$ & 1993 \\
Solar Village & $350 \mathrm{~kW}$ & 1981 \\
\hline
\end{tabular}


Given the ambitious renewable energy targets the country has set for itself, application of PV in buildings is an important avenue that needs attention in the form of strong policy framework and active follow up plans. Application of PV has been revolutionized across the world through some very successful policies such as feed-in-tariff (FIT) and net-metering. Germany, having pioneered the FIT, has become the global leader in solar PV, thanks to PV application in buildings. The FIT and net-metering policies have been adopted by over 50 countries in the world. It is time for Saudi Arabia to develop proactive policies on similar grounds to motivate the building sector to use PV systems. Besides supporting the consumer, utility also needs to be on board and policies like renewable obligation certificate (ROC) can be greatly helpful in this respect.

\section{The Case Study Area}

The King Fahd University of Petroleum and Minerals (KFUPM) is one of the largest university campuses in Saudi Arabia located in the city of Dhahran in the Eastern Province of KSA. Dhahran is located in the Eastern Province of Saudi Arabia. It is situated at $26^{\circ} 18^{\prime} 29^{\prime \prime}$ North, and $50^{\circ} 9^{\prime} 1^{\prime \prime}$ East, with a mean elevation of $62 \mathrm{~m}$ above sea level. Dhahran has a relatively modest solar radiation level at the national scale, still reaching to an annual figure of around $2100 \mathrm{kWh} / \mathrm{m}^{2}$ as indicated in Figure 4 . Further detailed overview of the solar energy potential of Dhahran is highlighted in Table 2.

Like the rest of the country, KFUPM is also experiencing a rapid growth in infrastructure for similar trends i.e., rise in number of students and staff, development of new buildings, labs and other infrastructure and modernization. The KFUPM campus is selected as the study area of the research as in terms of population, infrastructure and utilities requirements it resembles a small city and fits well with the scope of the work. For example, it has wide range of building types including various types of residences, shopping centers, community centers, sport centers, academic and administration blocks, student housing, schools, restaurants, medical center, workshops, warehouses and multipurpose buildings, as can been in Figure 5. The solar radiation levels at the site are provided in Table 2.

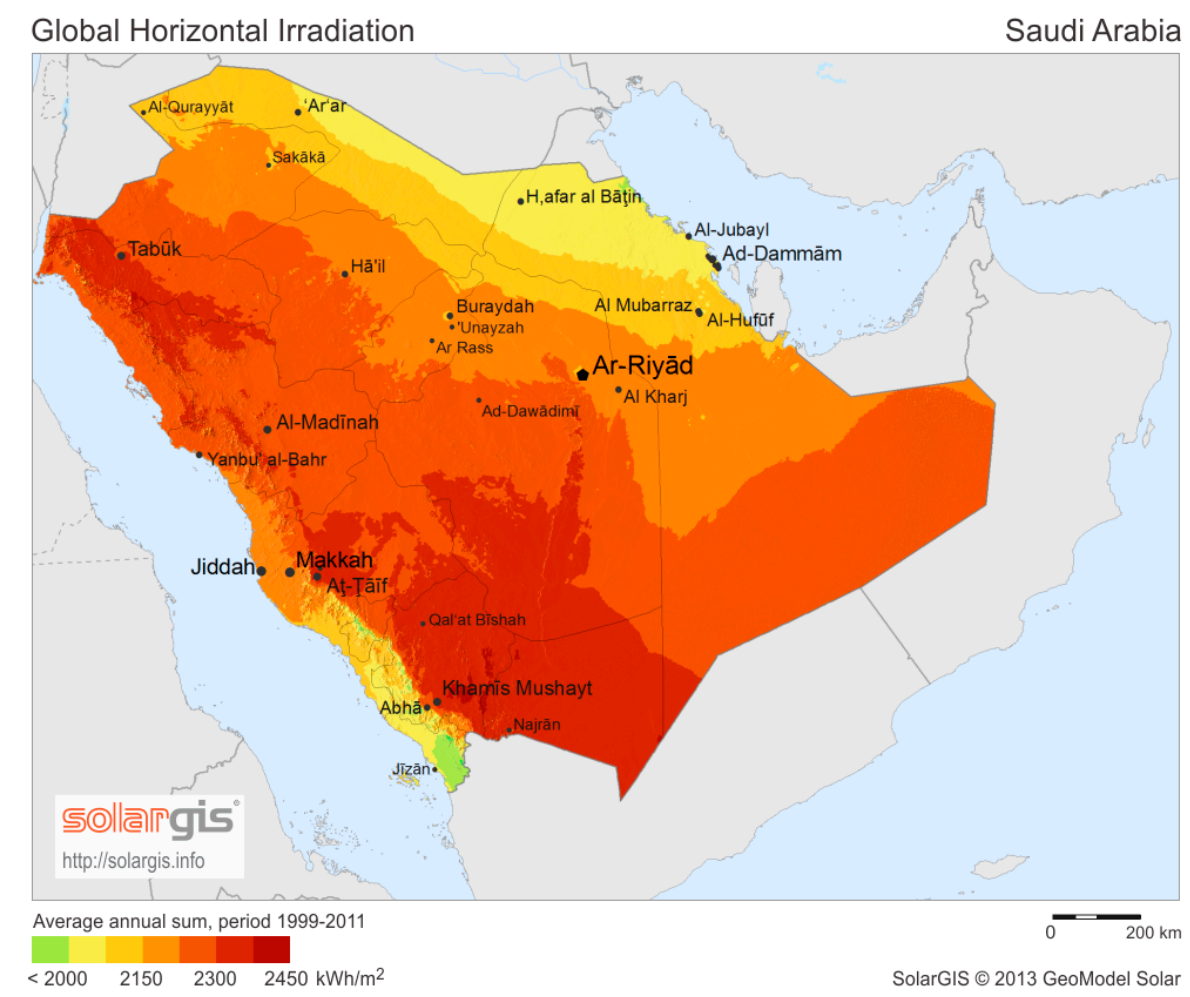

Figure 4. Solar energy potential of KSA. 


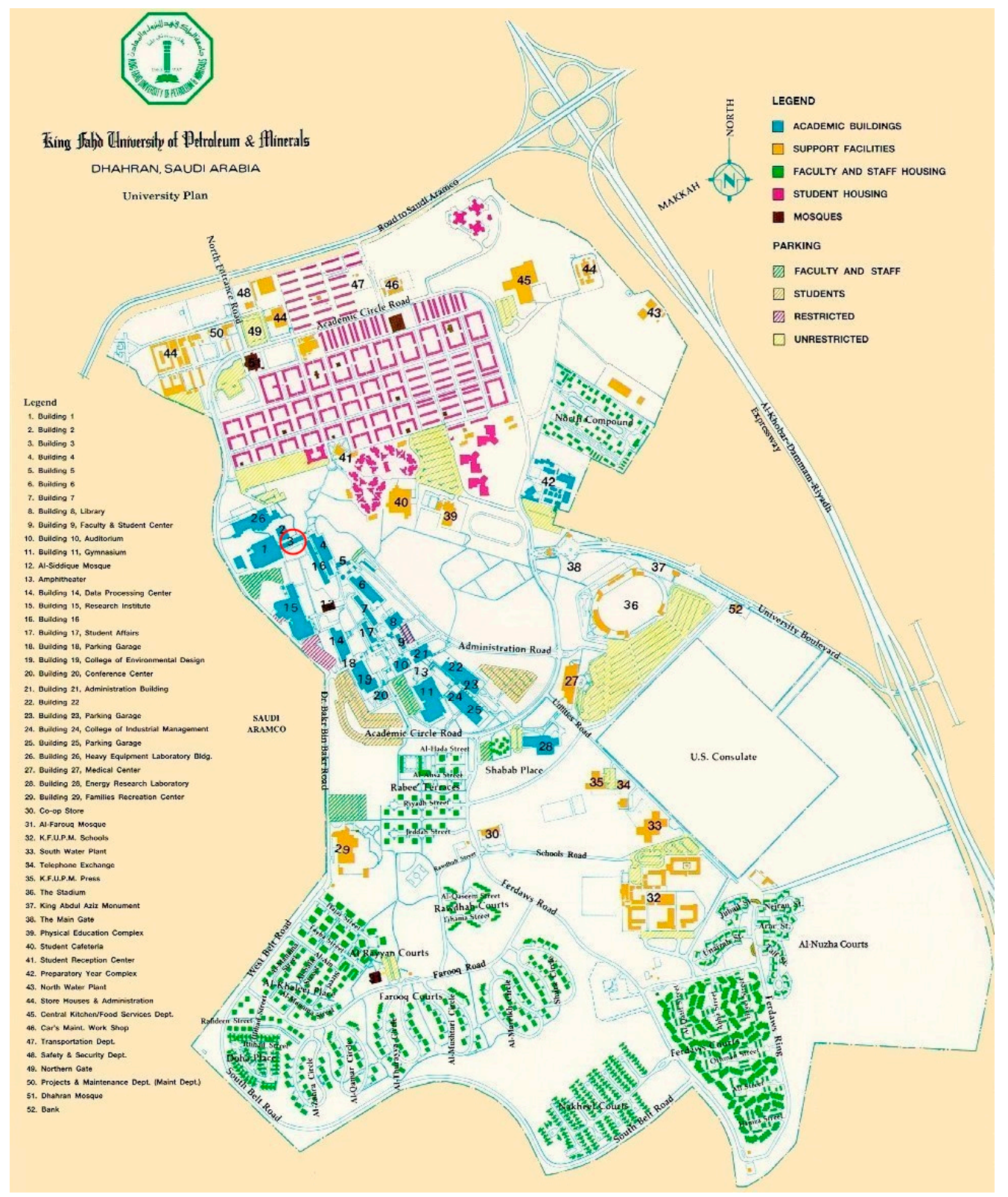

Figure 5. Overview of the KFUPM campus.

Table 2. Annual irradiation incident on Dhahran.

\begin{tabular}{ccccc}
\hline Month & Hh $\left(\mathbf{W h} / \mathbf{m}^{2} /\right.$ Day $)$ & Hopt. $\left(\mathbf{W h} / \mathbf{m}^{\mathbf{2}} /\right.$ Day $)$ & DNI $\left(\mathbf{W h} / \mathbf{m}^{\mathbf{2}} /\right.$ Day $)$ & Iopt. (Deg.) \\
\hline January & 3880 & 5090 & 4360 & 52 \\
February & 4800 & 5830 & 4810 & 43 \\
March & 6070 & 6730 & 5580 & 30 \\
April & 6600 & 6670 & 5540 & 14 \\
May & 7790 & 7340 & 6750 & 1 \\
June & 8320 & 7520 & 7720 & 0 \\
July & 7860 & 7270 & 6800 & 1 \\
August & 7440 & 7310 & 6620 & 9 \\
September & 6910 & 7450 & 6910 & 25 \\
October & 5750 & 6870 & 6340 & 40 \\
November & 4170 & 5320 & 4430 & 49 \\
December & 3730 & 5040 & 4450 & 54 \\
Year & 6120 & 6540 & 5870 & 24 \\
\hline
\end{tabular}

Hh: Irradiation on horizontal plane; Hopt.: Irradiation on optimally inclined plane; DNI: Direct normal irradiation; Iopt.: Optimal inclination. 


\section{PV Design Calculations}

Estimation of the availability of area for PV installation is one of the fundamental design requirements. The present study focuses on the rooftop area for PV installation. In terms of roof construction, KFUPM is exclusively composed of buildings with flat rooftops. The total roof area available on various types of buildings in the campus has been calculated with the help of ArcGIS 10.2 as shown in Table 3.

Table 3. KFUPM building types along with respective areas.

\begin{tabular}{cc}
\hline Building Type & Total Roof Area $\mathbf{( m}^{\mathbf{2}} \mathbf{~}$ \\
\hline Academic buildings * & 97,232 \\
Support facilities ** & 130,711 \\
Faculty housing & 157,153 \\
Student housing & 91,299 \\
Workshops and warehouses & 17,338 \\
Mosques \& community centers & 11,432 \\
Parking areas & 352,244 \\
Total Area & 857,408 \\
\hline
\end{tabular}

* Academic buildings: teaching blocks, science labs and administration blocks; ** Support facilities: schools, sports centers, shopping centers, restaurants and medical clinic.

PV cannot cover all of the roof areas mainly due to spacing required for shadow adjustment and any structural features, i.e., HVAC systems, skylights and staircases. The utilizable area therefore needs to be calculated taking into account these obstacles. The impact of shadow is influenced by the tilt angle of PV panels. Space between successive rows of PV panels has to be allocated to avoid the effect of shadow on panels and also to undertake cleaning and maintenance work. The car parking buildings also have their roofs used as parking space, leaving no room for PV systems. Given the unavailability of the car parking roof areas for PV application, they are not being included in the effectively available area and are hence excluded in calculations from here onwards. Table 4 provides percentages of roof area that can be used for PV for a sample building from each type.

Table 4. PV installation estimates for sample buildings from each building type.

\begin{tabular}{lcccccc}
\hline & $\begin{array}{c}\text { Academic } \\
\text { Building }\end{array}$ & $\begin{array}{c}\text { Faculty } \\
\text { Housing }\end{array}$ & $\begin{array}{c}\text { Support } \\
\text { Facility }\end{array}$ & $\begin{array}{c}\text { Student } \\
\text { Housing }\end{array}$ & Workshop & $\begin{array}{c}\text { Community } \\
\text { Center }\end{array}$ \\
\hline Roof area $\left(\mathrm{m}^{2}\right)$ & 7411 & 235 & 4800 & 1300 & 120 & 537 \\
Utilizable area $\left(\mathrm{m}^{2}\right)$ & 6886 & 157 & 4295 & 1094 & 120 & 479 \\
Utilizable roof area & 43 & 38 & 44 & 40 & 41 & 39 \\
used for PV (\%) & 1781 & 36 & 1135 & 267 & 30 & 113 \\
Number of PV Panels & 2393 & 59 & 1873 & 441 & 50 & 186 \\
Area of PVs $\left(\mathrm{m}^{2}\right)$ & & 59 & & & & \\
\hline
\end{tabular}

PV type: mono crystalline panels; PV panel dimensions: $1.65 \mathrm{~m} \times 1 \mathrm{~m}$; Tilt angle: $24^{\circ}$; Azimuth angle: $180^{\circ}$.

Different types of buildings make varying degree of its roof area available for solar PV depending upon their architectural and construction features and utilization. The difference between the proportions of utilizable roof area of these buildings for PV use seems to be in close proximity, $38 \%$ to $44 \%$. The total available area in different categories of campus buildings has been estimated in Table 5. 
Table 5. Total roof top areas for KFUPM.

\begin{tabular}{cccc}
\hline Building Type & $\begin{array}{c}\text { Total Roof Area } \\
\left(\mathbf{( m}^{\mathbf{2}} \mathbf{n}\right.\end{array}$ & $\begin{array}{c}\text { Utilizable Roof Area for PV } \\
\mathbf{( \% )}\end{array}$ & $\begin{array}{c}\text { Total Area of PV Panels } \\
\left(\mathbf{m}^{\mathbf{2}} \mathbf{)}\right.\end{array}$ \\
\hline Academic buildings & 97,232 & 40 & 38,893 \\
Support facilities & 130,711 & 39 & 50,977 \\
Faculty housing & 157,153 & 25 & 39,288 \\
Student housing & 91,299 & 34 & 31,042 \\
Workshops and warehouses & 17,338 & 41 & 7109 \\
Mosques \& community centers & 11,432 & 35 & 4001 \\
Total & 505,165 & 34 & 171,301 \\
\hline
\end{tabular}

Table 5 shows how at the urban level, utilizability of rooftops for PV application can vary in terms of building typology. It is observed that for different types of buildings the net utilizable area for PV use varies between $25 \%$ and $41 \%$. Overall, $34 \%$ of the total available rooftop area can be utilized for PV application. Typical residential buildings, faculty housing in this case, offer the least for PV application, mainly due to hurdles like satellite dish antenna, HVAC systems and stair cases. Industrial buildings, represented by workshops and warehouses in the study area, on the other hand, offer the greatest potential for having less crowded rooftops with these obstructive features.

\section{PV Output Modelling}

For the calculated utilizable roof area the energy production from the installed solar panels has been estimated with the help of PVsyst software employing the Dhahran weather conditions. Specimen energy yield calculations for the academic buildings are provided in Figure 6 and Table 6. Figure 7 specifically provides a detailed flow diagram of PV energy production from academic buildings, while also highlighting the involved losses at various stages.

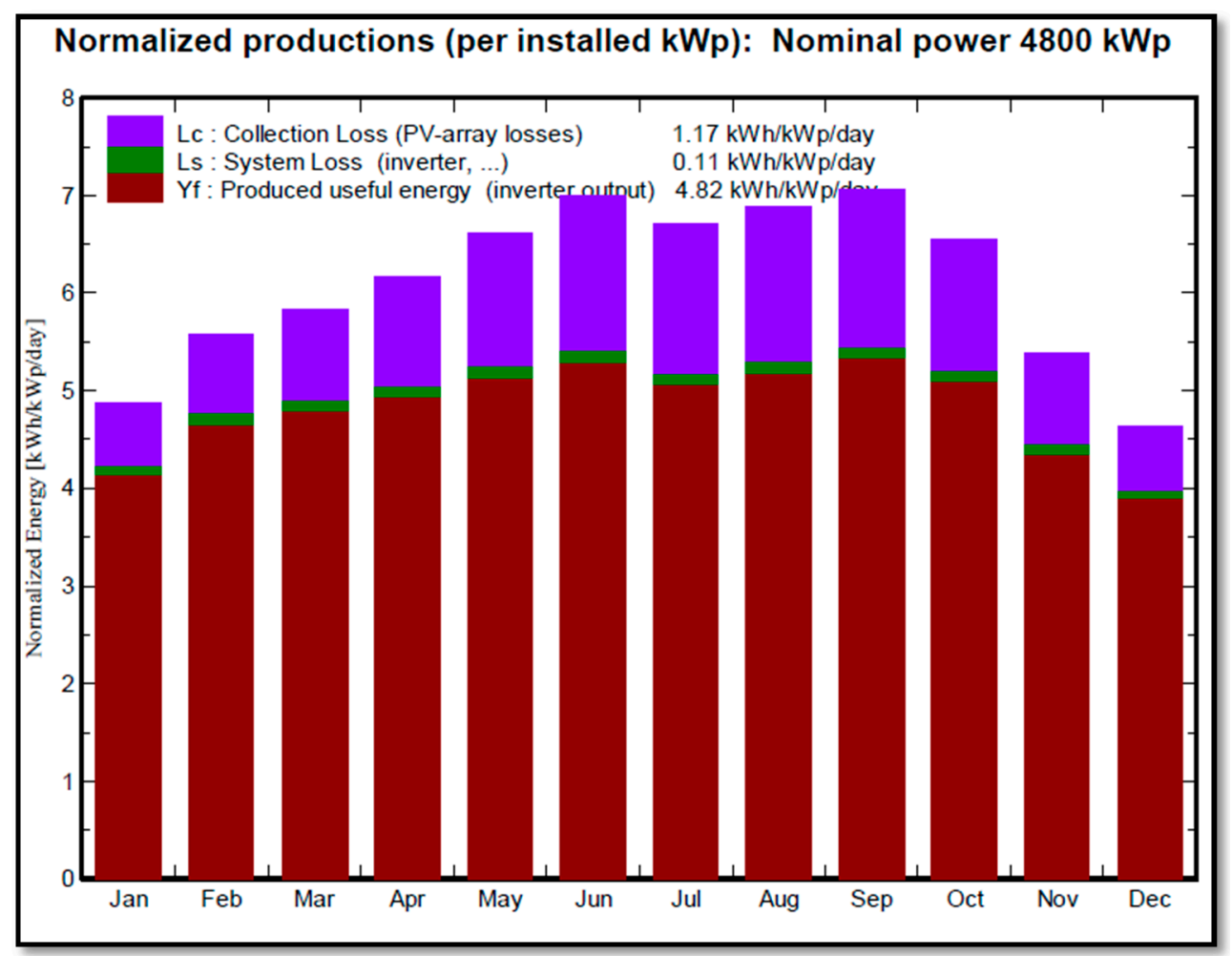

Figure 6. Normalized productions for academic buildings. 
Table 6. Output results for academic buildings.

\begin{tabular}{cc}
\hline System Parameter & Output \\
\hline Number of PV modules & 19,200 \\
Pnom total & $4800 \mathrm{kWp}$ \\
Number of inverters & 384 \\
Inverters Pnom total & $4608 \mathrm{~kW} \cdot \mathrm{AC}$ \\
Produced Energy & $8450 \mathrm{MWh} /$ year \\
Specific production & $1760 \mathrm{kWh} / \mathrm{kWp} /$ year \\
Performance ratio & $78.9 \%$ \\
\hline
\end{tabular}

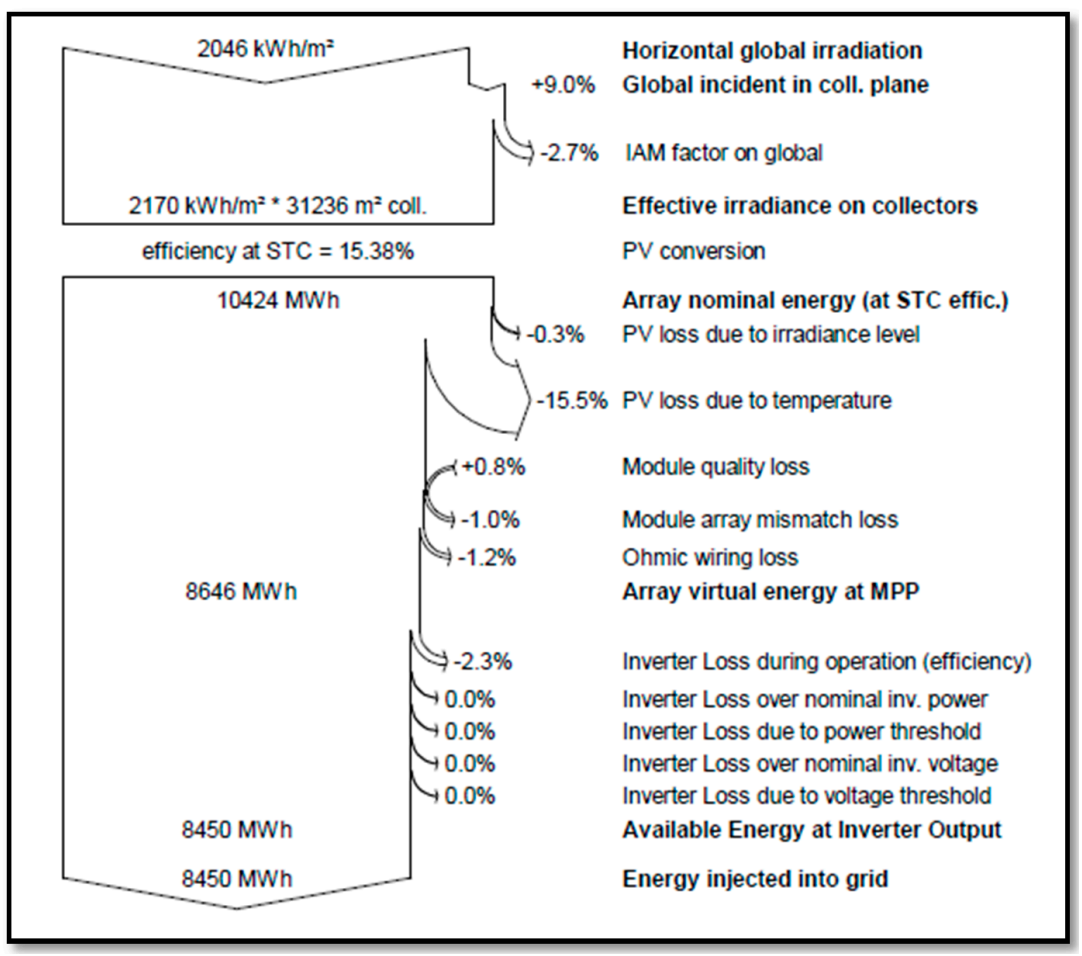

Figure 7. Loss diagram for academic buildings.

The total energy production from different types of buildings has been summarized in Table 7 . It can be seen that the annual total energy yield from the PV systems on all university buildings turns out to be 37,746 MWh. For the generated amount of energy, greenhouse gas emissions saved have also been calculated with the help of RetScreen software suggesting a total annual saving of 30,875 Metric tons $\mathrm{CO}_{2} \mathrm{e}$.

Table 7. Energy production and subsequent emission reduction through the rooftop PV systems in KFUPM.

\begin{tabular}{ccc}
\hline Building Type & $\begin{array}{c}\text { Energy Produced } \\
\text { (MWh) }\end{array}$ & $\begin{array}{c}\text { Emissions Reduction } \\
\left.\text { (Metric Tons } \mathbf{C O}_{\mathbf{2}} \mathbf{e}\right)\end{array}$ \\
\hline Academic buildings & 8450 & 6912 \\
Support facilities & 11,223 & 9180 \\
Faculty housing & 8871 & 7256 \\
Student housing & 6733 & 5508 \\
Workshops and warehouses & 1571 & 1285 \\
Mosques \& community centers & 898 & 734 \\
Total & 37,746 & 30,875 \\
\hline
\end{tabular}


KFUPM is experiencing a growing trend in energy demand with figure for the year 2015 estimated as 235,591 MWh, as indicated in Table 8.

Table 8. Annual electricity consumption trend in KFUPM.

\begin{tabular}{cc}
\hline Year & Annual Consumption (MWh) \\
\hline 2003 & 175,242 \\
2006 & 218,623 \\
2009 & 185,406 \\
2012 & 229,936 \\
2015 & 235,591 \\
\hline
\end{tabular}

The output from the PV systems on all KFUPM buildings, 37,746 MWh, turns out to be over $16 \%$ of the total KFUPM demand. This is a significant contribution that can be potentially made by rooftop PV systems in KFUPM. It will not only help reduce burden on national grid but also add to the sustainability of the campus by producing green and environmentally friendly energy.

\section{Conclusions}

The study investigates the prospects of the application of PV systems in buildings in Saudi Arabia by taking the King Fahd University of Petroleum and Minerals (KFUPM) as a case study. The total rooftop area available on all KFUPM buildings has been calculated to be 505,165 $\mathrm{m}^{2}$. Taking into account the necessary shadow avoidance spacing and obstructive features on building roofs such as HVAC systems, TV satellite dishes, stair cases and skylights, a net area of $171,310 \mathrm{~m}^{2}$ has been found to be utilizable for PV systems. For different types of buildings the utilizable area has been found to be in the range of $25 \%-41 \%$, with residential buildings having the least potential. The modelling exercise undertaken with the help of PVsyst software reveals that the PV cells receiving an annual irradiance of $2170 \mathrm{kWh} \cdot \mathrm{m}^{2}$ exhibit a performance ratio of $79 \%$. The system loss analysis suggests that the single greatest penalty is due to temperature with a value of $15.5 \%$. Results indicate that 37,746 MWh of electricity can be annually generated from the installed rooftop PV systems resulting in environmental emission savings of 30,875 metric tons of $\mathrm{CO}_{2} \mathrm{e}$. It is noted that over $16 \%$ of the total energy requirements of the KFUPM campus can be met through these systems. Use of environmentally friendly technologies like PV can significantly help the building and energy sectors become more sustainable. It can also help the power sector shave down peak load demands. In recent years, countries across the world have experienced a rapid growth in PV installation driven by conducive policies such as feed-in tariffs, net-metering and renewable obligation certificates. Feed-in tariffs in particular have propelled the PV applications in buildings in over 50 countries, and Saudi Arabia also needs explore it as a way forward.

Acknowledgments: The author appreciate the support by the Deanship of Scientific Research at the KFUPM to financially support towards completion of this work.

Conflicts of Interest: The author declares no conflict of interest.

\section{References}

1. Renewable Energy Policy Network for the 21st Century (REN21). World Renewable Global Status Report; RNE21 Secretaria: Paris, France, 2016.

2. Meza, E. Installed PV capacity at 227 GW worldwide. PV Mag. 2016. Available online: http://www.pvmagazine.com/news/details/beitrag/iea-pvps-installed-pv-capacity-at-227-gw-worldwide_100024068/\#axz z4OAOCb3IC (accessed on 30 September 2016).

3. Stoker, L. UK Solar Industry Hits $10 \mathrm{GW}$ Cumulative PV Capacity. Solar Power Portal. Available online: http://www.solarpowerportal.co.uk/news/exclusive_uk_solar_industry_hits_10gw_cumulative_ pv_capacity_3728 (accessed on 16 February 2016). 
4. Solar UK (SUK). Progress with PV Deployment under FiTs. Available online: http://www.uksolar.org.uk/3progress-with-pv-deployment-under-fits / (accessed on 29 September 2016).

5. Ismail, A.; Ramirez-Iniguez, R.; Asif, M.; Munir, A. Progress of solar photovoltaic in ASEAN countries: A review. Renew. Sustain. Energy Rev. 2015, 48, 399-412. [CrossRef]

6. Asif, M. Growth and sustainability trends in the GCC countries with particular reference to KSA and UAE. Renew. Sustain. Energy Rev. 2016, 55, 1267-1273. [CrossRef]

7. Alrashed, F.; Asif, M. Climatic classification of Saudi Arabia for building energy modelling. Energy Procedia 2015, 75, 1425-1430. [CrossRef]

8. Central Department of Statistics and Information (CDSI). Population Statistics Database. 2014. Available online: http://www.stats.gov.sa/sites/default/files/estm_pop_2016_4.pdf (accessed on 26 October 2016).

9. Sidawi, B. Hindrances to the financing of affordable housing in the Kingdom of Saudi Arabia. Emir. J. Eng. Res. 2009, 14, 73-82.

10. Alrashed, F.; Asif, M. Prospects of renewable energy to promote zero-energy residential buildings in Saudi Arabia. Energy Procedia 2012, 18, 1096-1105. [CrossRef]

11. Wikimedia Commons. Available online: https://commons.wikimedia.org/wiki/File:SolarGIS-Solar-mapSaudi-Arabia-en.png (accessed on 29 July 2016).

12. Saudi Energy Efficiency Centre (SEEC). 2014. Available online: http://www.seec.gov.sa/2013/03/27/\%d9\% $85 \% \mathrm{~d} 8 \% \mathrm{a} 8 \% \mathrm{~d} 8 \% \mathrm{a} 7 \% \mathrm{~d} 9 \% 86 \% \mathrm{~d} 9 \% 8 \mathrm{a} /$ ?lang=en (accessed on 29 July 2016).

13. Ministry of Water and Electricity (MWE). Electricity: Growth and Development in the Kingdom of Saudi Arabia; Information \& Statistic Center: Riyadh, Saudi Arabia, 2009.

14. Alrashed, F; Asif, M. An Exploratory of Residents' Views towards Applying Renewable Energy Systems in Saudi Dwellings. Energy Procedia 2015, 75, 1341-1347. [CrossRef]

15. Obaid, R.; Mufti, A. Present state, challenge, and future of power generation in Saudi Arabia. In Proceedings of the IEEE Energy 2030, Atlanta, GA, USA, 17-18 November 2008; pp. 1-6.

16. Alrashed, F.; Asif, M. Trends in residential energy consumption in Saudi Arabia with particular reference to the eastern province. J. Sustain. Dev. Energy Water Environ. Syst. 2014, 2, 376-387. [CrossRef]

17. Statista. Global Electricity Prices by Select Countries in 2015 (in U.S. Dollar Cents per Kilowatt Hour). Available online: http://www.statista.com/statistics/263492/electricity-prices-in-selected-countries / (accessed on 30 September 2016).

18. Electricity and Cogeneration Regulatory Authority (ECRA). 2015 Electricity Data; Electricity and Cogeneration Regulatory Authority: Riyadh, Saudi Arabia, 2016.

19. Arab News. KSA Power Demand Posts 8\% Average Annual Growth Rate. 2014. Available online: http://www.arabnews.com/news/549756 (accessed on 29 September 2016).

20. King Abdullah University of Science \& Technology (KAUST). Appraisal and Evaluation of Energy Utilization $\mathcal{E}$ Efficiency in the Kingdome of Saudi Arabia; King Abdullah University of Science \& Technology: Thuwal, Saudi Arabia, 2014.

21. Pothecary, S. Saudi Arabia Announces New Renewable Energy Target with Few Details of Deployment. PV Mag. 2016. Available online: http://www.pv-magazine.com/news/details/beitrag/saudi-arabiaannounces-new-renewable-energy-target-with-few-details-of-deployment_100024304/\#axzz4OAOCb3IC (accessed on 29 September 2016).

22. Hurair, F.S.; Hasnain, S.M.; Alawaji, S.H. Lessons learned from solar energy projects in Saudi Arabia. Renew. Energy 1996, 9, 1144-1147.

23. Golderberg, S. Masdar's Zero-Carbon Dream could Become World's First Green Ghost Town. The Guardian, 2016. Available online: https://www.theguardian.com/environment/2016/feb/16/masdars-zero-carbondream-could-become-worlds-first-green-ghost-town (accessed on 29 September 2016).

24. Masdar. Masdar City at a Glance. Available online: http://www.masdar.ae/en/masdar-city/detail/masdarcity-at-a-glance (accessed on 30 September 2016).

25. Desert Solar Saudi Arabia (DSSA). Top Solar Projects in Saudi Arabia. 2016. Available online: http://desertsolarsaudiarabia.com/top-10-solar-projects-ksa/ (accessed on 30 September 2016).

(C) 2016 by the author; licensee MDPI, Basel, Switzerland. This article is an open access article distributed under the terms and conditions of the Creative Commons Attribution (CC-BY) license (http://creativecommons.org/licenses/by/4.0/). 